fibroblasts of a patient with Ehers-Danlos syndrome type VII. F Biol Chem 1989;264:16804-9.

23 Hirano M, Tamaru Y, Nagai Y, Ito H, Imai T, Ueno S. Exon skipping caused by a base substitution at a splice site in the GTP cyclohydrolase I gene in a Japanese family with hereditary progressive dystonia dopa responsive dystonia Biochem Biophys Res Commun 1995;213:645-51.
24 Furukawa Y, Shimadzu M, Rajput AH, et al. GTPcyclohydrolase I gene mutations in hereditary progressive and dopa-responsive dystonia. Ann Neurol 1996;39:609-

25 Ichinose $\mathrm{H}$, Ohye T, Segawa M, et al. GTP cyclohydrolase I gene in hereditary progressive dystonia with marked diurnal fluctuation. Neurosci Lett 1995;196:5-8.

\title{
HISTORICAL NOTES
}

\section{Binswanger's "encephalitis subcorticalis chronica progressiva"}

Otto Binswanger (1852-1929), Professor of Psychiatry in Jena, in 1894 described eight patients with a progressive dementia punctuated by apoplectiform focal attacks whose brains showed diffuse or patchy but selective white matter atrophy, most marked in the temporooccipital regions with ventricular dilatation. He called it "encephalitis subcorticalis chronica progressiva". His original description is often misquoted but Förstl's translation now makes Binswanger's work accessible ${ }^{1}$ :

\footnotetext{
CLINICAL CRITERIA ( $\mathrm{p}$ 1184)

"The disease begins at the onset of senility (early in the fifties) or in advanced old age (early in the sixties);

"slow impairment of intellectual capabilities manifesting primarily by the progressive impairment and ultimate loss of the association between cortical sensory and motor areas;

"most frequently observed are aphasic disturbances (as in the present case), hemiamblyopia or hemianopia, hemiparesis with loss of the sense of pressure, position or touch; these circumscribed deficits are of a stable character during the fully developed disease and they are combined with the slow and relentless deterioration of intellectual performances; ( . . .until) the patients resemble decerebrate laboratory animals."

NEUROPATHOLOGICAL CRITERIA (p 1137)

"We find a pronounced atrophy of the hemispheric white matter, either restricted to one or more gyri in one brain area or of several hemispheric regions affected with variable severity;

"these changes are most clearly found in the area of the occipital and temporal lobes, so that temporal and occipital horns are widened into bag-like cavities, while the anterior portion of the lateral ventricle shows relatively little enlargement and the frontal white matter is almost unaffected by the disease process... The cortex does not show any remarkable macroscopic change apart from a slight narrowing. Invariably, these cases show severe atheroma of the cerebral arteries. . it is very likely that the subcortical loss of fibres is caused by a deficiency of the blood supply resulting from arteriosclerosis.”

Binswanger did not describe the microscopic pathology, but Alzheimer did give a more detailed account of
}

the histology, and named the condition "Binswanger's disease." Alzheimer reported:

"One can show in the white matter, the presence of more or less numerous foci which produce wide areas of secondary degeneration... Usually the foci are also to be found in the internal capsule, the lenticular nucleus, the thalamus, and particularly in the pons in the region of the pyramidal tract... caused by a particularly severe arteriosclerosis of the long vessels deep in the white matter with intense atrophy of the white matter." ${ }^{2}$

The distinction from senile dementia, general paralysis of the insane, and mixed Alzheimer's disease with multi-infarct disease remained confused, both clinically and pathologically. ${ }^{3}$ Nissl also characterised the vascular pathology of Binswanger's disease and much later Bennett $e t a l^{4}$ attempted to standardise the antemortem diagnosis. Necessary features were: dementia, bilateral radiological abnormalities (CT or MRI), and two of the following: vascular risk factors; focal cerebrovascular disease; "subcortical" cerebral dysfunction.

J M S PEARCE 304 Beverley Road, Anlaby, East Yorks HU10 $7 B G, U K$

1 Binswanger O. Die Abgrenzung der allgemeinen progressiven Paralyse, I-III. Berl Klin Wochenschr 1894;49:1103-5, 1137-9, 1180-6. (Translation by H Förstl et al. Binswanger on Binswanger's disease and presentation of 2 cases. Intern 7 Geriatr Psychiat 1991;6:529-35.)

2 Alzheimer A. Die seelenstorungen auf arteriosclerotischer grundlage. Allgemeine Zeitschrift fur Psychiatrie 1902;59: 695-9.

3 Olszewski J. Subcortical arteriosclerotic encephalopathy: review of the literature of so called Binswanger's disease and presentation of two cases. World Neurology 1962:3:35975 .

4 Bennett DA, Wilson RS, Gilley DW, Fox JH. Clinical diagnosis of Binswanger's disease. F Neurol Neurosurg Psychiatry 1990;53:961-5. 